\begin{tabular}{|l|l|l||}
\hline \multicolumn{2}{|c|}{ PublisherInfo } \\
\hline \hline PublisherName & $:$ & BioMed Central \\
\hline \hline PublisherLocation & $:$ & London \\
\hline \hline PublisherImprintName & $:$ & BioMed Central \\
\hline \hline
\end{tabular}

\title{
Dolly, version 3.0
}

\begin{tabular}{|l|l|l||}
\hline \multicolumn{2}{|c|}{ ArticleInfo } \\
\hline \hline ArticleID & $:$ & 3717 \\
\hline \hline ArticleDOI & $:$ & $10.1186 /$ gb-spotlight-20000704-02 \\
\hline \hline ArticleCitationID & $:$ & spotlight-20000704-02 \\
\hline \hline ArticleSequenceNumber & $:$ & 154 \\
\hline \hline ArticleCategory & $:$ & Research news \\
\hline ArticleFirstPage & $:$ & 1 \\
\hline \hline ArticleLastPage & $:$ & 2 \\
\hline \hline & $:$ & RegistrationDate : 2000-07-04 \\
ArticleHistory & $:$ & OnlineDate $: 2000-07-04$ \\
\hline \hline ArticleCopyright & $:$ & BioMed Central Ltd2000 \\
\hline \hline ArticleGrants & $:$ & \\
\hline \hline ArticleContext & $:$ & 130591111 \\
\hline \hline
\end{tabular}




\section{William Wells}

Email: wells@biotext.com

McCreath et al. report in the 29 June Nature that they have achieved gene modification in sheep by directed integration into the DNA of a fibroblast, followed by nuclear transfer to generate three adult clones (Nature 2000, 405:1066-1069). The cloning step avoids the need to isolate embryonic stem (ES) cells, which has proven impossible thus far for livestock species. The new method also improves on the random integration events of traditional transgenesis by allowing endogenous genes to be modified and new genes to be inserted at specific sites in the genome. McCreath et al. integrate their constructs into a transcriptionally active collagen gene with targeting efficiencies similar to those seen in mouse ES cells. The inclusion of an ovine $\beta$-lactoglobulin promoter drives protein production from the inserted gene, al-antitrypsin, in the sheep's milk at higher levels than with any previous transgenic animal. Future targeting events may focus on inactivating the PrP gene, which is necessary for scrapie transmission, or ablating xenoreactive transplantation antigens.

\section{References}

1. Nautre magazine, [http://www.nature.com/nature/]

2. Insertion of DNA sequences into the human chromosomal beta-globin locus by homologous recombination.

3. Viable offspring derived from fetal and adult mammalian cells. 